\title{
Land in the Mountainous and Foothill Zone of Azerbaijan
}

\author{
Rae ZH Aliyev* \\ Institute erosion and irrigation of NAS Azerbaijan, Azerbaijan
}

Submission: October 11, 2018; Published: November 13, 2018

*Corresponding author: Rae ZH Aliyev, Institute erosion and irrigation of NAS Azerbaijan, Azerbaijan

\begin{abstract}
As a result of the erosion process, most of the mountainous and foothill regions of our Republic have lost their fertility. Complex recovery measures should be taken to restore lost fertility. For this purpose, the ecological condition of landscapes should be taken into consideration in the soil vegetation of natural zones, climatic conditions.
\end{abstract}

Keywords: Soil erosion; Landscape; Bias; Soil cover; Mode tverdochostoka

\section{Introduction}

Most of the mountainous and foothold areas of Azerbaijan have been exposed to erosion and have lost their fertility. In order to restore and maintain the fertility of erosive lands, zonal complex anti-erosion measures should be undertaken. When applying combat measures, soil-vegetation cover of natural zones, climatic conditions, degree of soil erosion, slope tendencies and ecological conditions of landscapes should be taken into account (Figure 1).

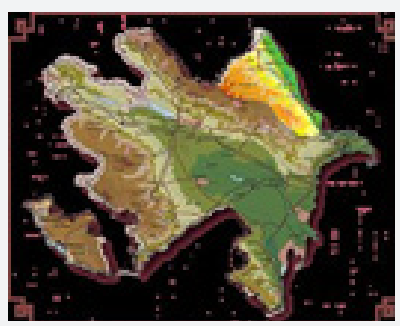

Figure 1: Result of the erosion process.

Soil-vegetation cover, bio-gum and so on, in the territory of the Republic, including the Minor and the Greater Caucasus, rise from the sea level to the altitude. Accordingly, different natural areas are separated. Hydro technical, agrotechnical, phytomelorative (forest and grass melorma) measures should be implemented in complex and complementary conditions to protect soil cover from erosion.

In addressing the problem of land erosion, it is necessary to overcome the factors leading to its occurrence. First of all, economic and organizational measures should be taken. It is of utmost importance to use erosion and erosive lands more efficiently, to restore soil fertility, to ensure the proper location of farms, perennial plantings, forest strips and roads taking into account the relief structure and soil conditions.
Large-scale land surveys should be undertaken in order to design erosion measures, to properly organize the area and placement of agricultural crops on a scientific basis. A map of erosion factors and a map of anti-erosion measures should be drawn up for the study areas. The Scientific Research Institute of Erosion and Irrigation developed maps for a number of farms in mountainous and foothills regions of the Republic.

Land protection schemes should be applied on slopes up to 5o and in areas with poor and washed out areas where cultivated crops should be cultivated primarily. $20 \%$ of these turnover should be perennial herbaceous plants. The results of research conducted at the Erosion and Irrigation Institute over the past 30 years have shown that the 5-10을 slopes should dominate the grazing crops in a rotating sowing system and should not exceed $20-25 \%$ of the cultivated crops. Plants in perennial shrub transplants should have $25-30 \%$ perennial herbs.

Seedlings planted at the slopes of $10-15^{\circ}$ should be fully cropped up and crop rotation of perennial herbs should be up to $60 \%$ in the sowing system. In cultivated areas where severe erosion is required, cereal crops should be completely discontinued. In such areas, only perennial herbs should be planted. This event protects the soil from erosion well and is very economically beneficial. It is better to stop cultivation of field crops in areas with temperatures above $15^{\circ}$ and use them as natural fodder.

Anti-erosion control measures on the slopes (plowing and other cultivation works along the slope width, flooding of water and buffer strips, deep lubrication, etc.) improves the water-physical properties of the soil, prevents the surface flow and creates moisture in the soil. Thus, in the slopes with 8-10응 
slopes, the amount of soil that washed in the slopes is reduced by 2.5 times, humidity is $3-4 \%$ and fertility is $21.2 \%$.

It should be noted that on the sloping slopes, it is only possible to prevent the erosion process completely when it is pushed along the slope width. Additional anti-erosion measures should be undertaken on such slopes. One of these measures is the opening of the puddles that keep water in the direction of the slope when ice creeping. Rainfall prevents surface water flow and drainage, increases moisture content in soil, increases productivity of agricultural crops.

It has been established that deep softening of soil with strips in the prevention of erosion is of great economic significance. This measure prevents the surface flow of $75-80 \%$, the sediment is well ground to the soil, and so the water-physical property of the soil improves considerably.

Includes sulfurous agrotechnical measures Opening slots on the slopes is of great importance. Roughing, plowing, pasturing, mowing, and so on. The crops in the herbaceous herbaceous crops should be sprinkled in the autumn when the soil is condensed, and in the autumn sowing areas before sowing or in the soil. Reducing the water flow of the soil prevents its laundering, increases moisture content in the soil and thereby increases the productivity of agricultural crops. As it is known, the erosion process in the summer and winter pastures is widespread. Thus, more than $80 \%$ of summer pastures, and $60 \%$ of winter pastures have been exposed to erosion.

Therefore, it is necessary to keep cattle grazing and livestock breeding in order to meet the high nutritional requirements of livestock and to obtain high-quality feeds. Proper compliance with grooming time and norms will result in surface and basic improvements $90 \%$ of forests in the Republic are located in the mountainous areas. Their water-soluble and soil-protecting role is indispensable. Forests do not allow the flow of water and regulate the water regime. In addition, forests have a great resort value. However, as a result of forest breakage or cattle grazing, forest lands are eroded. For this reason, about $20 \%$ of the forests have been eroded in our study area. More than $80 \%$ of the underground forest was exposed to erosion.

Therefore, protection of forests should be given special attention, conditions should be created for good restoration, and measures should be taken to create new forests in open and dry areas. The erosion of the country is also widespread.

Cultivation erosion as a result of planting, knitting and so on. The spheres are broken down and become useless. So it is important to take measures to combat the ravine erosion. There are many extinctions in the mountainous and foothill regions of the Republic, that is, the developmental slopes.

On the slopes of these hills, it is possible to create fields to sow the seeds of perennial herbs, which also tighten the walls of the cup. When mounting the gobs, special attention should be paid to the development of forests in and around it. It is necessary to plant trees and bushes to fasten areas of rocks. In order to avoid sliding on slopes, it is necessary to direct the surface water flow to another location. To do this, drainage on the slopes should be used.

Hydrotechnical constructions should be used to protect river basins from erosion, floods in the Republic. These constructions help prevent the flood by sinking the coastal material that has been created as a result of the erosion process, protecting the coast of the river from collapsing. Along with water erosion, wind erosion is widespread throughout the territory of the Republic. The air conditioning process is one of the main factors causing erosion and occurs in the foothills of the Lesser Caucasus. Complex measures must be taken to prevent soil and sand from being drawn by winds. When planting forest strips, the dominant wind direction, strength and so on. Should be taken into account. The above-mentioned measures should be implemented in a coherent manner in order to protect the soil cover and to increase the efficiency of its use. If every farm fights correctly, the land is protected from rupture, its fertility increases, resulting in a higher and stable harvest of agricultural crops.

More than $20 \%$ of the territory of the Republic over the past 15 years has been occupied as a result of Armenia's aggression and has long turned into a bloody battleground. Here, military erosion has developed extensively. Toxic bombs, bullets and mortar missiles have destroyed hundreds of villages, towns, and several districts, ruining landscapes, demolishing the land, cutting off a thousand hectares and sowing their vineyards. It has poisoned and polluted the toxicological environment by using toxic substances during the war.

Such lands should be thoroughly cleaned with systematic and meliorative measures after their occupation and the land should be treated with special care. Here, complex measures must be taken to return the lands to agricultural turnover. The soil should be subjected to toxicology.

Zone genocide has also occurred in the area that has turned into a battlefield. Thus, in the war-ravaged areas, all creatures have fled, and there is no chance to find sparrows here. All these have created ecosides that have eradicated ecosystems, disrupted natural resources, and hit the situation. it is necessary to undertake complex, melorative and special measures in the areas to be named [1-3].

\section{References}

1. Aliyev BH, Aliyev ZH (2000) Problems of erosion in Azerbaijan and its solution. Search for: ЗИЛ ИНПЦ Нурлан. Baku-2000 p.122.

2. Aslanov ГК (1999) Melioration on the gray territories of Azerbaijan". . Baku "Science" Summary In progress soil erosion in mountain and foothills of the fertility. To this end, it is necessary to have at least one aspect of the climate, covering vegetation, and even naturally environmental aspect decision.

3. Mammadov Q, Khalilov M (2004) Ecology and the environment. Baku "Science", p. 505. 
Your next submission with Juniper Publishers will reach you the below assets

- Quality Editorial service

- Swift Peer Review

- Reprints availability

- E-prints Service

- Manuscript Podcast for convenient understanding

- Global attainment for your research

- Manuscript accessibility in different formats ( Pdf, E-pub, Full Text, Audio)

- Unceasing customer service

Track the below URL for one-step submission https://juniperpublishers.com/online-submission.php 